\title{
Soil aggregation and carbon stabilization in burn and no- burn sugarcane management systems
}

\author{
MARIA DE FÁTIMA GUIMARÃES ${ }^{1}$, JOSÉ F. DE OLIVEIRA ${ }^{2}$, TIAGO S. TELLES ${ }^{2}$, \\ WALQUÍRIA MACHADO ${ }^{1}$, GRAZIELA M.C. BARBOSA ${ }^{2}$ and JOÃO TAVARES FILHO ${ }^{1}$ \\ ${ }^{1}$ Departamento de Agronomia, Centro de Ciências Agrárias, Universidade Estadual de \\ Londrina, Rod. Celso Garcia Cid, Km 380, 86057-970 Londrina, PR, Brazil \\ ${ }^{2}$ Instituto Agronômico do Paraná, Rod. Celso Garcia Cid, Km 375, Caixa Postal 10030, 86057-970 Londrina, PR, Brazil
}

Manuscript received on October 2, 2017; accepted for publication on October 30, 2017

\begin{abstract}
Retaining sugarcane straw over the soil after harvesting can improve soil structure and increase soil carbon stabilization, mainly in macroaggregates. We evaluated the carbon content in the aggregate classes in areas under burn and no-burn (adopted for five years) sugarcane management systems, focusing on the superficial layer (0.00-0.20 m). The experiment was carried in an Oxisol and the treatments consisted in burnt sugarcane, manual harvest; burnt sugarcane, mechanized harvest; and no-burn, mechanized harvest. The retention of sugarcane straw on the soil surface is justified by the increase in carbon content and carbon stock in the surface layer $(0.00-0.20 \mathrm{~m})$ by restructuring of the soil, even though it cannot match the structure of the soil under native forest. Our results suggest that in no-burn management the carbon not occluded inside aggregates was important to increase carbon stabilization in soil and that more attention should be given to macroaggregates $2.00-8.00 \mathrm{~mm}$ present in this management system, that showed higher carbon content and was responsible for increase of the geometric and weight diameter, increasing the erosion resistance in the long term in relation to burn systems.
\end{abstract}

Key words: sugarcane straw, soil aggregates, carbon stock, sand fraction, soil structure.

\section{INTRODUCTION}

Sugarcane (Saccharum spp.) is a semi-perennial crop used in the food industry and for the production of biofuels (ethanol), animal feed, fibers and energy. It is one of the most important crops grown with a global cultivation area of over 20 million ha in more than 100 countries (FAO 2014). Brazil is

Correspondence to: Tiago Santos Telles

E-mail: telles@iapar.br

* Contribution to the centenary of the Brazilian Academy of Sciences. one of the world's biggest producers of sugarcane, responsible for one-third of global ethanol fuel production. To supply the Brazilian demand and part of the global demand for ethanol in 2021, it is estimated that more than 6.4 million hectares of additional cane land will be required (Goldemberg et al. 2014).

The challenge is to find a sugarcane management system that is economically and environmentally sustainable. Burning sugarcane straw is a common method used to facilitate harvesting and transportation. More than 16 million 
tons of sugarcane straw is burned in the world and the countries with more quantities of crop residues burned are Brazil, India and China (FAO 2014). This practice decreases soil organic carbon levels compared to soil in its natural condition (Razafimbelo et al. 2006). Bearing in mind that organic carbon is a major factor in enhancing the productive capacity of tropical soils, these losses can be up to 30\% compared to native forest (Don et al. 2011) or grassland (Mello et al. 2014), increasing the risks of the erosion and soil degradation.

Retaining sugarcane straw on the surface (noburn management) is one possibility for improving soil quality and cutting the risks of erosion and soil degradation. Increases in soil aggregation and organic carbon stabilization due to sugarcane management changes, from pre-harvest burning to no-burn harvest are reported in the literature (Anaya and Huber-Sannwald 2015), especially under Brazilian soils (Cerri et al. 2011, Souza et al. 2012). However, the results of the benefits of retaining the sugarcane straw on the soil surface for organic carbon stabilization is not consistent (Thorburn et al. 2012). Thus, further research about the effects of retaining sugarcane straw on tropical soil quality are necessary (Cerri et al. 2011), mainly about soil physical indicators and management practices that alleviate negative impacts on these attributes, in sugarcane producing areas (Cherubin et al. 2016a).

In analyzing the quality or degradation intensity of the soil, the superficial layer $(0.00$ and $0.20 \mathrm{~m}$ ) sustains the initial adverse impact of the management method and degradation of the soil. This layer exhibits the main alterations in bulk density, aggregate classes and organic carbon caused by soil management for sugarcane cropping, as observed by Razafimbelo et al. (2006), Souza et al. (2012), Rossi et al. (2013) and Hunke et al. (2015).

Bearing in mind that organic carbon content falls dramatically when mechanization is used
(Balesdent et al. 2000, Kay and VandenBygaart 2002) and that the drop in carbon content with depth is more pronounced in clay soils than sandy soils (Desjardins et al. 2004), the 0.00-0.20 m layer is the main focus of studies on carbon stock along a changs of land use in Brazil (Batlle-Bayer et al. 2010). Analysis of the $0.00-0.20 \mathrm{~m}$ layer can help to understand the effects of sugarcane production management on soil structure degradation and carbon accumulation in the different classes of soil aggregates.

Therefore, the aim of the study was to evaluate if the soil structure degradation and carbon content in different aggregate classes are affected by sugarcane management systems with burn and noburn preharvest.

\section{MATERIALS AND METHODS}

The experiment was conducted in 2011, in Paraguaçu Paulista, State of São Paulo, Brazil (22 $\left.29^{\prime} \mathrm{S}, 5^{\circ} 37^{\prime} \mathrm{W}\right)$ (Figure 1). The soil was developed on Bauru Group sandstone and is classified as an Oxisol [dystrophic Red Latosol according to Santos et al. (2006)], of medium texture (Table I). The relief is gently undulating with slopes ranging from 3 to $8 \%$. The primary vegetation is savanna Cerrado. The $0.00-0.20 \mathrm{~m}$ layer was classified as silt-sandy with clay content between 372 and $388 \mathrm{~g} \mathrm{~kg}^{-1}$ and particle density between 2.70 and $2.78 \mathrm{Mg} \mathrm{dm}^{-3}$. In the Köppen system, the climate is classified as humid subtropical (Cwa), with average temperatures of over $22^{\circ} \mathrm{C}$ in summer and below $18{ }^{\circ} \mathrm{C}$ in winter, and average annual rainfall of $1.359 \mathrm{~mm}$. The study was conducted in a commercial area of the sugarcane factory Nova America/COSAN. The area under sugarcane treatments had 15 ha and the remaining area of native forest was of 3 ha. Before being turned over to sugarcane, the area was used for growing maize (Zea mays L.), soybean (Glycine max (L.) Merr.) and cotton (Gossypium hirsutum L.). The 
area had been cropped to sugarcane (Saccharum spp.; sugarcane is named without a defined species because modern commercial varieties are founded on interspecific hybrids between Saccharum sponta-neum and Saccharum officinarum) since 1992, and on each cycle of five to seven slashes, the plantation is overhauled. When the samples used in this study were collected, the plantation was on the third harvest, this year of a variety of $S$. officinarum.

A fully randomized experimental design was used, with four treatments and twenty replications. The treatments consisted of three harvesting systems: (i) sugarcane with burn and manual harvest (BMn); (ii) sugarcane with burn and mechanized harvest (BMc); (iii) sugarcane without burn and mechanized harvest (NBMc). In all three systems, the sugarcane was loaded mechanically using a tractor and dump trailer. The areas have been established with these treatments since 1992, therefore for 19 years when the samples were taken, in 2011. In the area with burning, sugarcane was burned every year from the second year, therefore 19 times when the soil sampling from this study was taken. The mechanized harvesting without straw burn started after the burning in 2002; therefore, a nine-year period without burning was accumulated at the time of soil sampling in 2011. However, every five to seven harvests, the sugarcane is renewed (replanted) and the straw is incorporated with plowing and scarification to a depth of 0.50 $\mathrm{m}$. The last replanting of the sugarcane was carried out in 2008, three years before the soil sampling. In the harvest system without burn, the harvester had an extractor-crusher to reduce the size of the straw.

The adjacent savanna native forest (NF) was used as a reference for the initial condition of the soil before it was turned over to farming. Areas with or without burning were located side by side, and the remaining native forest was located perpendicular to both areas.
Soil samples were collected immediately after harvesting the sugarcane, at a depth of 0.00-0.20 m. For each treatment, a sampling area of $2 \mathrm{~km} \times 2 \mathrm{~km}$ was established, with 20 samples randomly collected, and composed of four discrete sub-samples, two from the sugarcane rows and two from the interrows. Sampling was performed with the aid of GPS, georeferenced on a regular grid of $20 \mathrm{~m} \times 10 \mathrm{~m}$. We met all the basic principles of experimentation, repetition and randomization; areas under sugarcane were homogeneous, with the same soil type, cultivar of sugarcane, the same weather conditions; they have also received the same amount of fertilizers and pesticides.

Soil density was determined using the volume cylinder method $\left(100 \mathrm{~cm}^{3}\right.$ cylinder $)$ as in Donagema et al. (2011). Aggregate stability was determined using the wet sieving method (Yoder 1936), adapted by Castro Filho et al. (1998), and sieve meshes of $8.00,4.00,2.00,1.00,0.50$ and $0.25 \mathrm{~mm}$. The soil sample was saturated with water by capillary action for 10 minutes before beginning wet-sieving for 15 minutes. The water-stable aggregates retained by the sieves were dried at $105{ }^{\circ} \mathrm{C}$ for 24 hours. The proportion of each class of aggregates was obtained and used to calculate the geometric mean diameter (GMD) and mean weight diameter (MWD), according to Castro Filho et al. (1998). Using the same set of sieves, the soil samples were used to determine the total organic carbon content for each aggregate class. Total carbon in each aggregate class was determined by wet oxidation using potassium dichromate, as described in Donagema et al. (2011). The carbon content was used to calculate the carbon stock per unit area (expressed in $\mathrm{kg} \mathrm{m}^{-2}, \mathrm{Ct}$ ), using the equation $C t=C s x d x L$, where $C s=$ carbon content in $\mathrm{g} \mathrm{g}^{-1}, d=$ soil density $\left(\mathrm{kg} \mathrm{m}^{-3}\right)$ and $L=$ layer thickness (m) (Batjes 1996, Desjardins et al. 2004).

The data was subjected to normality testing and variance homogeneity. The results were subjected to analysis of variance and the means compared 


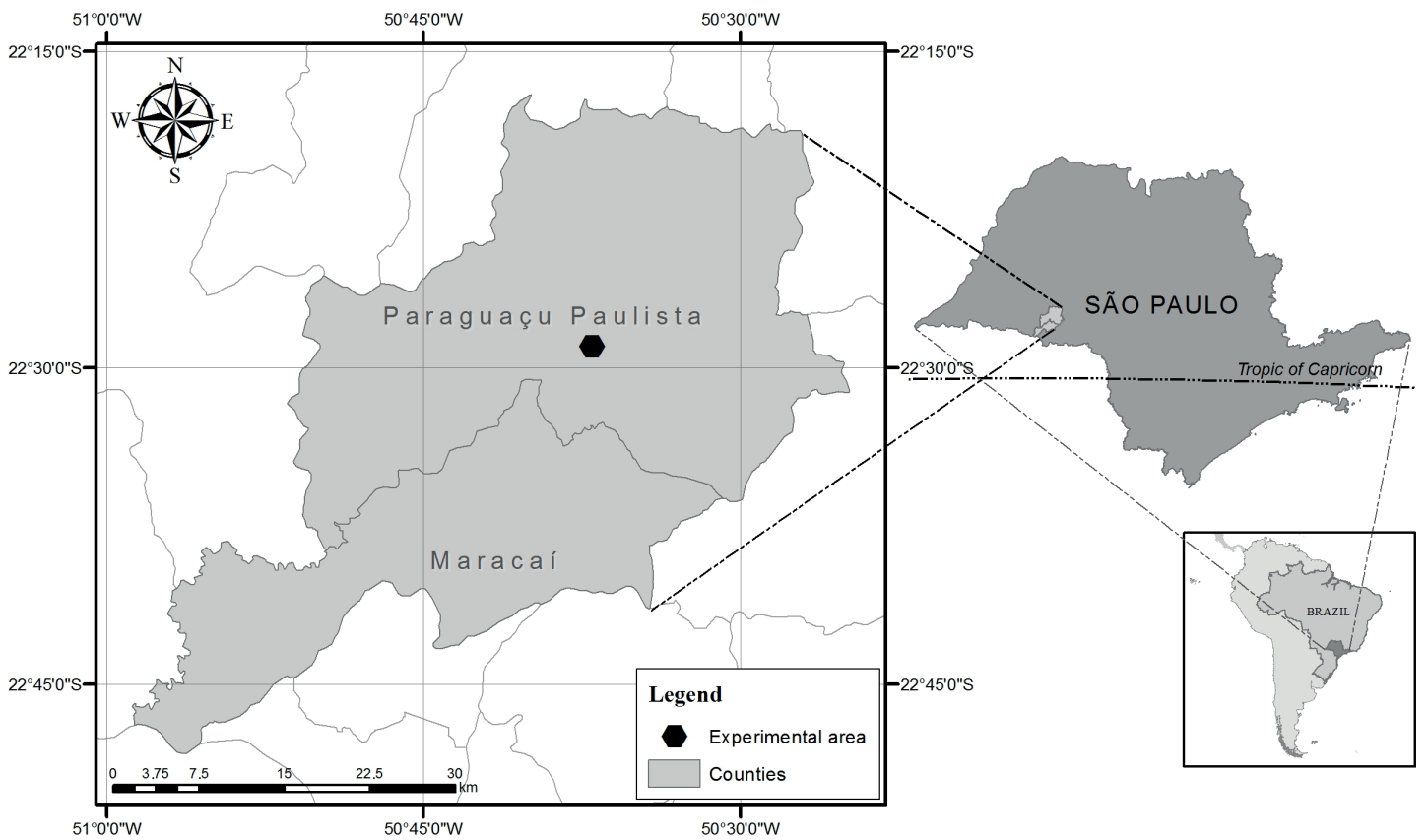

Figure 1 - Map of Brazil showing the state of São Paulo, map of São Paulo state showing the municipalities and the map of municipalities, showing the approximate localization of the experimental area.

TABLE I

Characteristics of the 0 - 0.20 m layer of a medium-textured dystrophic Red Latosol under native forest (NF) and different sugarcane harvesting systems.

\begin{tabular}{|c|c|c|c|c|}
\hline \multirow{2}{*}{ Treatment } & \multicolumn{3}{|c|}{ Particle-size distribution } & \multirow{2}{*}{ Pd } \\
\hline & Clay & Silt & Total Sand & \\
\hline & \multicolumn{3}{|c|}{$\longrightarrow \mathrm{g} \mathrm{kg}^{-1} \longrightarrow$} & $-\mathrm{Mg} \mathrm{m}^{-3}-$ \\
\hline NF & 379 & 239 & 382 & 2.78 \\
\hline $\mathrm{BMn}^{1}$ & 387 & 234 & 379 & 2.77 \\
\hline $\mathrm{BMc}$ & 388 & 233 & 379 & 2.75 \\
\hline NBMc & 372 & 243 & 385 & 2.70 \\
\hline
\end{tabular}

NF: native forest. BMn: sugarcane with burn and manual harvest. BMc: sugarcane with burn and mechanized harvest. NBMc: sugarcane without burn and mechanized harvest. Pd: particle density.

using the Tukey test $(\mathrm{p}<0.05)$. For the purposes of discussion, Pearson correlation was also used $(p<0.05)$. All statistical analyses were performed using $\mathrm{SAS}^{\circledR}$ software.

\section{RESULTS}

The change use of the soil for sugarcane production decreased total organic carbon in the soil and organic carbon in the aggregate classes, irrespective of the diameter and the management system, such reduction may reach $66 \%$ in systems with burns and
$50 \%$ in the system with maintenance of sugarcane straw (Table II). Native forest had the highest C content in all aggregate classes compared to all sugarcane management systems, with the highest carbon contents found in classes above $0.50 \mathrm{~mm}$ (Table II). The $\mathrm{C}$ stock at a depth of $0.20 \mathrm{~m}$ under Native forest $\left(1.05 \mathrm{~kg} \mathrm{~m}^{-2}\right)$, twice the amount found in soils under sugarcane (Figure 2).

The NBMc system, between 0.25 and 4.00 $\mathrm{mm}$, was the best sugarcane management system, exhibiting the highest carbon content, concentrated 
mainly outside aggregates (57\%) and in aggregates of diameter ranging from 4.00 to $8.00 \mathrm{~mm}$, in relation to burn systems (Table II). Consequently, the organic carbon stock $\left(\mathrm{kg} \mathrm{m}^{-2}\right)$ was higher under conservation system than under burn systems (Figure 2). The carbon stock is correlated with improved soil structure. The higher values of GMD and MWD and increase of aggregates between $0.50-4.00 \mathrm{~mm}$ are positively correlated with an increase in the carbon stock in the $0.00-0.20 \mathrm{~m}$ layer. The carbon stock is negatively correlated with the aggregates smaller than $0.5 \mathrm{~mm}$ (Table III).

The use of the soil for sugarcane production decreased macroaggregates between 0.25 and $4.00 \mathrm{~mm}$, irrespective of the management system. The fragment of native forest presented better aggregation, with lowest microaggregate mass $(<0.25 \mathrm{~mm})$ and the highest macroaggregate between 0.50 and $4.00 \mathrm{~mm}$ (Table IV). However, the NBMc system exhibited the best soil structure compared to the other management systems, with highest values for MWD and GMD, highest macroaggregate of the class 2.0-4.0 $\mathrm{mm}$ and lowest mass of aggregates with diameter between 0.5 and $0.250 \mathrm{~mm}$. The BMn and BMc systems exhibited similar values for MWD, GMD and aggregate class distribution (Table IV).

\section{DISCUSSION}

Land use change for sugarcane production decreased the content and stabilization of the carbon in surface layer of the soil. The soil under NF presented the highest carbon stock, followed by NBMc system with a decrease of $46 \%$ in carbon stock. Under the burn systems, the decrease compared to NF was around $65 \%$, irrespective of the type of harvesting system (Figure 2). In Brazil, the sugarcane production has decreased the structural soil quality in relation to native forest and pastures (Cherubin et al. 2016b).
Between sugarcane managements, the NBMc was the better system, with higher carbon stocks and better soil structure (Table II and Figure 2). The increase in carbon content under the NBMc system resulted in a $20 \%$ rise in carbon stocks $\left(\mathrm{kg} \mathrm{m}^{-2}\right)$ by comparison with the straw burn system. The absence of soil perturbation on tillage and retaining sugarcane straw over the soil could explain these results. This may have been due to the addition of free carbon that is non-complexed, unprotected, labile, stabilized outside of the aggregates and can persist for longer periods in the soil (Balesdent et al. 2000). In the area of this study, in 2008, Souza et al. (2012) observed, in 0.00-0.20 m layer, that the carbon not occluded inside aggregate increased $46 \%$ under no-burn system compared to the burn system, and in 2011, we observed that $57 \%$ of the carbon are not occluded inside aggregates (Table II), suggesting that there was an increase of $11 \%$ of the carbon stabilization outside aggregates, with three years of no burn management. Wander and Bidart (2000) and Gerzabek et al. (2006) observed that, under no-till systems retaining sugarcane straw and regardless of particle-size distribution, one of the main sources of carbon in the soil was particulate carbon. In Australia, Cambardella and Elliott (1992), studying soil consisting of around $30 \%$ clay under different management systems, observed that, of the total carbon in soil under native forest, over $35 \%$ was found in particulate form, and that when subjected to plowing and tilling, this proportion dropped to $18 \%$ and with retaining the sugarcane straw under a no-till system, particulate carbon content increased to $25 \%$ of total carbon in the soil.

In another point of view, part of the increase in carbon levels under the NBMc can be explained by occlusion of the carbon within aggregates, especially in those between 4.00-8.00 mm (Table II). The macroaggregates with this diameter are formed mainly by roots, mycelium and glomalin of arbuscular mycorrhizal fungus (Wright et al. 2007), 
and the decomposition of roots and straw retained on the soil surface may sustain the occurrence of these microbiological processes.

The increased carbon content under the NBMc system can be also explained by the cation bridge mechanism. Clays and organic matter have a predominance of negative charges, and the polyvalent cations act as bridges for interaction between clay particles and organic molecules (Oades 1988). This author observed that the $\mathrm{Ca}^{2+}$ and $\mathrm{Fe}^{3+}$ are major cations involved in bridge formation.

It is important to consider that the carbon dynamic within aggregate classes increases the chances of contact with complex mineral-carbon, enhancing the stability and permanence of the carbon in the soil, even after it has been disturbed to replant the sugarcane. Desjardins et al. (2004) reported that a significant fraction of particulate carbon can be rapidly incorporated by finer fractions.

In burn systems, of $50 \%$ to $70 \%$ of the carbon was stabilized within aggregates (Table II) and with this, it is possible that the predominant carbon fraction is complexed by clays, pyromorphic humus (González-Pérez et al. 2004) or in the form of charcoal. In tropical soils containing around 30\% clay, Cambardella and Elliott (1992) observed the presence of up to $10 \%$ of total carbon in the form of charcoal, produced by burning native forest. In our study, this fraction should represent a higher percentage of total carbon, capable of reaching $30 \%$, because of the frequency with which the sugarcane straw is burned, as reported by DeLuca and Aplet (2008) for agroecosystems with a propensity to catch fire.

It was expected the correlation of the carbon with aggregation and improvement of the soil structure (Table III). The increase of the MWD and GMD under native forest and the NBMc system may be a result of the decomposition of the carbon of the forest and sugarcane straw from three years earlier that stimulated the microbacterial activity

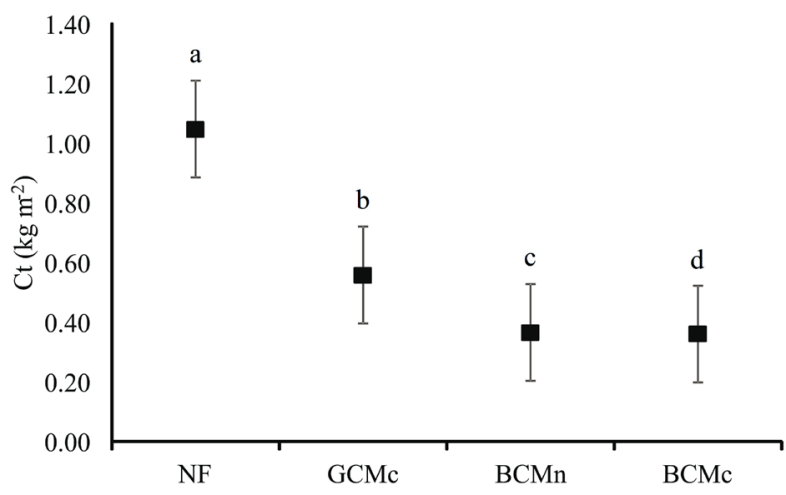

Figure 2 - Mean and confidence interval (95\%) of stock carbon per area in the fragment of native forest (NF) and in areas under the sugarcane with burn and manual harvest (BMn), sugarcane with burn and mechanized harvest (BMc) and sugarcane without burn and mechanized harvest (NBMc). Different letters represent significant differences in the Tukey test $(\mathrm{p}<0.05)$.

TABLE II

Total organic carbon content in a medium-textured dystrophic Red Latosol in a fragment of native forest (NF) and in sugarcane cropping areas under the sugarcane with burn and manual harvest (BMn), sugarcane with burn and mechanized harvest (BMc) and sugarcane without burn and mechanized harvest (NBMc).

\begin{tabular}{|c|c|c|c|c|c|c|c|c|}
\hline \multirow{2}{*}{ Treatment } & \multicolumn{6}{|c|}{ Aggregate classes } & \multicolumn{2}{|c|}{ Total C } \\
\hline & $>8$ & 8.0-4.0 & 4.0-2.0 & 2.0-1.0 & $1.0-0.5$ & $0.5-0.250$ & $\sum$ Classes & Soil \\
\hline & \multicolumn{6}{|c|}{$\longrightarrow \mathrm{mg} \mathrm{C} \mathrm{g}^{-1}$} & \multicolumn{2}{|c|}{$-\mathrm{g} \mathrm{C} \mathrm{kg}^{-1}$} \\
\hline NF & $22.21 \mathrm{Aa}^{2}$ & $20.91 \mathrm{Aa}$ & $22.77 \mathrm{Aa}$ & $23.47 \mathrm{Aa}$ & $24.58 \mathrm{Aa}$ & $14.50 \mathrm{Ba}$ & $10.61 \mathrm{a}$ & $16.43 \mathrm{a}$ \\
\hline $\mathrm{BMn}$ & $9.72 \mathrm{Ab}$ & $4.96 \mathrm{Bc}$ & $7.42 \mathrm{ABb}$ & $8.98 \mathrm{Ab}$ & $6.26 \mathrm{ABb}$ & $2.58 \mathrm{Cb}$ & $3.99 \mathrm{~b}$ & $5.44 \mathrm{c}$ \\
\hline $\mathrm{BMc}$ & $5.35 \mathrm{Ab}$ & $4.92 \mathrm{Ac}$ & $5.07 \mathrm{Ac}$ & $4.57 \mathrm{ABc}$ & $3.96 \mathrm{BCc}$ & $1.80 \mathrm{Cc}$ & $2.58 \mathrm{c}$ & $5.26 \mathrm{c}$ \\
\hline NBMc & $6.67 \mathrm{Ab}$ & $6.11 \mathrm{Ab}$ & $7.16 \mathrm{Ab}$ & $5.93 \mathrm{Ac}$ & $6.47 \mathrm{Ab}$ & $2.75 \mathrm{Bb}$ & $3.50 \mathrm{~b}$ & $8.09 \mathrm{~b}$ \\
\hline
\end{tabular}

Different uppercase letters in the row and lowercase letters in the column indicate significant differences in the Tukey test $(\mathrm{p}<0.05)$. 
TABLE III

Correlation coefficient of the geometric mean diameter (GMD) and mean weight diameter (MWD) of aggregates of diameter $>8.00,8.00-4.00,0.50-0.25$ and $<0.25 \mathrm{~mm}$ with carbon concentration $\left(\mathrm{kg} \mathrm{m}^{-2}\right)$ in a medium-textured dystrophic Red Latosol.

\begin{tabular}{cccccccccc}
\hline & GMD & MWD & $>8$ & $8.0-4.0$ & $4.0-2.0$ & $2.0-1.0$ & $1.0-0.5$ & $0.5-0.250$ & $<0.250$ \\
\hline $\mathrm{Ct}$ & $0.652^{*}$ & $0.556^{*}$ & $0.106^{\mathrm{NS}}$ & $0.377^{*}$ & $0.777^{*}$ & $0.753^{*}$ & $0.727 *$ & $-0.362 *$ & $-0.501 *$ \\
\hline
\end{tabular}

* Significant 5\%. NS: non-significant.

TABLE IV

Classes of aggregates in a medium-textured dystrophic Red Latosol in a fragment of native forest (NF) and areas cropped with sugarcane under sugarcane with burn and manual harvest (BMn), sugarcane with burn and mechanized harvest (BMc) and sugarcane without burn and mechanized harvest (NBMc).

\begin{tabular}{|c|c|c|c|c|c|c|c|c|c|}
\hline Treatment & GMD & MWD & $>8$ & $8.0-4.0$ & $4.0-2.0$ & $2.0-1.0$ & $1.0-0.5$ & $0.5-0.250$ & $<0.250$ \\
\hline \multicolumn{4}{|c|}{$-\mathbf{m m}-$} & \multicolumn{6}{|c|}{$\mathbf{g}$} \\
\hline NF & $0.53 \mathrm{a}$ & $1.32 \mathrm{a}$ & $2.08 \mathrm{a}$ & $4.59 \mathrm{a}$ & $4.06 \mathrm{a}$ & $3.28 \mathrm{a}$ & $4.94 \mathrm{a}$ & $13.53 \mathrm{~b}$ & $16.63 \mathrm{~b}$ \\
\hline BMn & $0.34 \mathrm{~b}$ & $0.84 \mathrm{~b}$ & $1.19 \mathrm{a}$ & $3.19 \mathrm{a}$ & $1.18 \mathrm{c}$ & $1.16 \mathrm{~b}$ & $2.73 \mathrm{~b}$ & $18.35 \mathrm{a}$ & $22.46 \mathrm{a}$ \\
\hline $\mathrm{BMc}$ & $0.36 \mathrm{~b}$ & $0.91 \mathrm{~b}$ & $1.77 \mathrm{a}$ & $3.66 \mathrm{a}$ & $1.61 \mathrm{c}$ & $1.56 \mathrm{~b}$ & $2.81 \mathrm{~b}$ & $17.83 \mathrm{a}$ & $21.37 \mathrm{ab}$ \\
\hline NBMc & $0.45 \mathrm{ab}$ & $1.30 \mathrm{a}$ & $4.05 \mathrm{a}$ & $4.78 \mathrm{a}$ & $2.44 \mathrm{~b}$ & $1.68 \mathrm{~b}$ & $3.18 \mathrm{~b}$ & $11.94 \mathrm{~b}$ & $22.61 \mathrm{a}$ \\
\hline
\end{tabular}

GMD: Geometric mean diameter. MWD: Mean weight diameter. Different letters in the column indicate significant differences in the Tukey test $(\mathrm{p}<0.05)$.

(Abiven et al. 2009, Souza et al. 2012, Tisdall and Oades 1979), mainly mycelium and glomalin of arbuscular mycorrhizal fungus (Wright et al. 2007) and controls directly the balance between the synthesis and degradation of materials, that help to structure the soil (Aspiras et al. 1971).

In soils with similar granularity to those in our study, Tisdall and Oades (1979) observed that the formation and stability of aggregates larger than $2.00 \mathrm{~mm}$ is due to the cementing effect of hyphae in the rhizosphere of grasses. It is also important to take into account the recovery of macrofauna activity (Kladivko 2001), since the combination of roots and worms can increase the formation and stability of aggregates by up to $6 \%$ in soils consisting of around 30\% clay (Fonte et al. 2012).

Burning introduces a less-reactive carbon into the soil, with short aliphatic and aromatic chains, and decreasing organic components that are precursors of polysaccharides (Almendros and González-Vila 2012). Moreover, after burning, there are carbon formations highly resistant to oxidation and biological degradation, with weak colloidal properties, enhanced resistance and low reactivity (González-Pérez et al. 2004). Suggesting that the less reactive carbon in burn system may explain the less aggregation and soil structuration in relation to NBMc.

The slow restructuring soil in NBMc, in relation to native forest (three years after renewal of the plantation) may be influenced by the medium-textured soil under investigation, the specific surface area of particles $>2 \mu \mathrm{m}$ (silt and sand) can range from 6 to $15 \mathrm{~m}^{2} \mathrm{~g}^{-1}$, considered negligible compared to particles $<2 \mu \mathrm{m}$ (Balbino et al. 2002a), with surface area of $\approx 60 \mathrm{~m}^{2} \mathrm{~g}^{-1}$ (Hodson 2002). Slow soil restructuring in Latosol with similar granulometry was observed by Balbino et al. (2002b). The authors observed that the macrostructure in these soils is fragile and easily altered, with low aggregate stability that has a strong link to the organic matter content.

In line with the findings of Razafimbelo et al. (2006) and Souza et al. (2012), we also found that retaining sugarcane straw over the soil increased the total organic carbon content of the soil and 
improved its structure. Thus, retaining sugarcane straw on the ground is justified by the resulting increase in macroaggregates and subsequent restructuring of the soil.

In synthesis, the retention of sugarcane straw on soil surface is justified by the increase in carbon content and carbon stock in this layer (0.00-0.20 $\mathrm{m}$ ) and the restructuring of the soil, even though it cannot match the structure of the soil under native forest. Under no-burn management system, the increase of the carbon stock $\left(\mathrm{kg}^{-1} \mathrm{~m}^{2}\right)$ in the surface layer occurred mainly with the carbon not occluded inside aggregates and in macroaggregates class 2.00-8.00 mm, which showed higher carbon content and was responsible for the increase of the geometric mean diameter and mean weight diameter, in relation to burn systems. In the noburn sugarcane straw the carbon stock dropped $46 \%$ compared to native forest, whereas under the burn systems, this decrease was around $65 \%$, irrespective of the type of harvesting system. Burning off the straw decreases macroaggregate mass and the soil's organic carbon stock.

\section{REFERENCES}

ABIVEN S, MENASSERI S AND CHENU C. 2009. The effects of organic inputs over time on soil aggregate stability - A literature analysis. Soil Biol Biochem 41: $1-12$.

ALMENDROS G AND GONZÁLEZ-VILA FJ. 2012. Wildfires, soil carbon balance and resilient organic matter in Mediterranean ecosystems. A review. Spanish J Soil Sci 2: 8-33.

ANAYA CA AND HUBER-SANNWALD E. 2015. Long-term soil organic carbon and nitrogen dynamics after conversion of tropical forest to traditional sugarcane agriculture in East Mexico. Soil Till Res 147: 20-29.

ASPIRAS RB, ALLEN ON, HARRIS RF AND CHESTERS G. 1971. The role of microorganisms in the stabilization of soil aggregates. Soil Biol Biochem 3: 347-353.

BALBINO LC, BROSSARD M, LEPRUN J-C AND BRUAND A. 2002a. Mise en valeur des Ferralsols de la région du Cerrado (Brésil) et évolution de leurs propriétés physiques: une étude bibliographique. Étude et Gestion Des Sols 9: 83-104.
BALBINO LC, BRUAND A, BROSSARD M, GRIMALDI M, HAJNOS M AND GUIMARÃES MF. 2002b. Changes in porosity and microaggregation in clayey Ferralsols of the Brazilian Cerrado on clearing for pasture. Eur J Soil Sci 53: 219-230.

BALESDENT J, CHENU C AND BALABANE M. 2000. Relationship of soil organic matter dynamics to physical protection and tillage. Soil Till Res 53: 215-230.

BATJES NH. 1996. Total carbon and nitrogen in the soils of the world. Eur J Soil Sci 47: 151-163.

BATLLE-BAYER L, BATJES NH AND BINDRABAN PS. 2010. Changes in organic carbon stocks upon land use conversion in the Brazilian Cerrado: A review. Agr Ecosyst Environ 137: 47-58.

CAMBARDELLA CA AND ELLIOTT ET. 1992. Particulate soil organic-matter changes across a grassland cultivation sequence. Soil Sci Soc Am J 56: 777-783.

CASTRO FILHO C, MUZILLI O AND PODANOSCHI AL. 1998. Estabilidade dos agregados e sua relação com o teor de carbono orgânico num Latossolo Roxo distrófico, em função de sistemas de plantio, rotações de culturas e métodos de preparo das amostras. Rev Bras Cienc Solo 22: $527-538$.

CERRI CC, GALDOS MV, MAIA SMF, BERNOUX M, FEIGL BJ, POWLSON D AND CERRI CEP. 2011. Effect of sugarcane harvesting systems on soil carbon stocks in Brazil: An examination of existing data. Eur J Soil Sci 62: 23-28.

CHERUBIN MR, KARLEN DL, CERRI CEP, FRANCO ALC, TORMENA CA, DAVIES CA AND CERRI CC. 2016a. Soil quality indexing strategies for evaluating sugarcane expansion in Brazil. PLoS ONE 11: e0150860.

CHERUBIN MR, KARLEN DL, FRANCO ALC, TORMENA CA, CERRI CEP, DAVIES CA AND CERRI CC. 2016b. Soil physical quality response to sugarcane expansion in Brazil. Geoderma 267: 156-168.

DELUCA TH AND APLET GH. 2008. Charcoal and carbon storage in forest soils of the Rocky Mountain West. Front Ecol Environ 6: 18-24.

DESJARDINS T, BARROS E, SARRAZIN M, GIRARDIN C AND MARIOTTI A. 2004. Effects of forest conversion to pasture on soil carbon content and dynamics in Brazilian Amazonia. Agr Ecosyst Environ 103: 365-373.

DON A, SCHUMACHER J AND FREIBAUER A. 2011. Impact of tropical land-use change on soil organic carbon stocks: A meta-analysis. Glob Change Biol 17: 1658-1670. DONAGEMA GK, CAMPOS DVB, CALDERANO SB, TEIXEIRA WG AND VIANA JHM. 2011. Manual de métodos de análise de solos, $2^{\mathrm{a}}$ ed., Rio de Janeiro: Embrapa Solos, 212 p.

FAO - THE FOOD AND AGRICULTURE ORGANIZATION OF THE UNITED NATIONS. 2014. FAO Statistics. 
Available at: http://faostat3.fao.org [Accessed on Oct 4, 2016].

FONTE SJ, QUINTERO DC, VELÁSQUEZ E AND LAVELLE P. 2012. Interactive effects of plants and earthworms on the physical stabilization of soil organic matter in aggregates. Plant Soil 359: 205-214.

GERZABEK MH, ANTIL RS, KOGEL-KNABNER I, KNICKER H, KIRCHMANN H AND HABERHAUER G. 2006. How are soil use and management reflected by soil organic matter characteristics: a spectroscopic approach. Eur J Soil Sci 57: 485-494.

GOLDEMBERG J, MELLO FFC, CERRI CEP, DAVIES CA AND CERRI CC. 2014. Meeting the global demand for biofuels in 2021 through sustainable land use change policy. Energ Policy 69: 14-18.

GONZÁLEZ-PÉREZ JA, GONZÁLEZ-VILA FJ, ALMENDROS G AND KNICKER H. 2004. The effect of fire on soil organic matter--a review. Environ Int 30: 855-870.

HODSON ME. 2002. Variation in element release rate from different mineral size fractions from the $\mathrm{B}$ horizon of a granitic podzol. Chem Geol 190: 91-112.

HUNKE P, ROLLER R, ZEILHOFER P, SCHRÖDER B AND MUELLER EN. 2015. Soil changes under different landuses in the Cerrado of Mato Grosso, Brazil. Geoderma Reg 4: 31-43.

KAY B AND VANDENBYGAART A. 2002. Conservation tillage and depth stratification of porosity and soil organic matter. Soil Till Res 66: 107-118.

KLADIVKO EJ. 2001. Tillage systems and soil ecology. Soil Till Res 61: 61-76.

MELLO FFC, CERRI CEP, DAVIES C, HOLBROOK NM, PAUSTIAN K, MAIA SMF, GALDOS MV, BERNOUX M AND CERRI CC. 2014. Payback time for soil carbon and sugar-cane ethanol. Nat Clim Change 4: 1-5.

OADES JM. 1988. The retention of organic matter in soils. Biogeochemistry 5: 35-70.
RAZAFIMBELO T, BARTHÈS B, LARRÉ-LARROUY MC, LUCA EF, LAURENT JY, CERRI CC AND FELLER C. 2006. Effect of sugarcane residue management (mulching versus burning) on organic matter in a clayey Oxisol from southern Brazil. Agr Ecosyst Environ 115: 285-289.

ROSSI CQ, PEREIRA MG, LOSS A, GAZOLLA PR, PERIN A AND DOS ANJOS LHC. 2013. Changes in soil C and N distribution assessed by natural $\delta 13 \mathrm{C}$ and $\delta 15 \mathrm{~N}$ abundance in a chronosequence of sugarcane crops managed with preharvest burning in a Cerrado area of Goiás, Brazil. Agr Ecosyst Environ 170: 36-44.

SANTOS HG, JACOMINE PKT, ANJOS LHC, OLIVEIRA VA, COELHO MR, LUMBRELAS JR AND CUNHAS TJF. 2006. Sistema brasileiro de classificação de solos, 2nd ed., Rio de Janeiro: EMBRAPA-SPI, 306 p.

SOUZA RA, TELLES TS, MACHADO W, HUNGRIA M, TAVARES FILHO J AND GUIMARÃES MF. 2012. Effects of sugarcane harvesting with burning on the chemical and microbiological properties of the soil. Agr Ecosyst Environ 155: 1-6.

THORBURN PJ, MEIER EA, COLLINS K AND ROBERTSON FA. 2012. Changes in soil carbon sequestration, fractionation and soil fertility in response to sugarcane residue retention are site-specific. Soil Till Res 120: 99-111.

TISDALL J AND OADES J. 1979. Stabilization of soil aggregates by the root systems of ryegrass. Aust J Soil Res 17: 429-441.

WANDER MM AND BIDART MG. 2000. Tillage practice influences on the physical protection, bioavailability and composition of particulate organic matter. Biol Fert Soils 32: 360-367.

WRIGHT S, GREEN V AND CAVIGELLI M. 2007. Glomalin in aggregate size classes from three different farming systems. Soil Till Res 94: 546-549.

YODER RE. 1936. A direct method of aggregate analysis of soil and a study of the physical nature erosion losses. J Am Soc Agron 28: 337-351 